\begin{tabular}{lll} 
KULTURA & $\begin{array}{l}\text { POLSKA A KADEMIA NAUK } \\
\text { KOMITET SOCJOLOGII }\end{array}$ & ISSN 0023-5172 \\
i & $\begin{array}{l}\text { INSTYTUT STUDIÓW POLITYCZNYCH } \\
\text { SPOLCLENSTWO nr } 2016, \text { WIDZIANE W MIEŚCIE }\end{array}$ & \\
\hline
\end{tabular}

ŁUKASZ ROGOWSKI

Uniwersytet im. Adama Mickiewicza w Poznaniu

\title{
WIDEOZWIEDZANIE BADANIA MIASTA W PERSPEKTYWIE PARADYGMATU MOBILNOŚCI
}

Klasycznie rozumiana socjologia jest socjologią statyczną. Z jednej strony oznacza to, że działania społeczne są zazwyczaj postrzegane jako realizowane w jednym miejscu, a przemieszczanie się jest raczej chwilową, a tym samym mało ważną czynnością występującą pomiędzy tymi działaniami. Nieruchomość jest traktowana jako coś normalnego i naturalnego. $Z$ drugiej strony pociąga to za sobą istotne konsekwencje epistemologiczne i metodologiczne. Statyczna perspektywa poznawania życia społecznego zakłada, że możliwe staje się wyodrębnienie względnie wyizolowanego układu aktorów i znaczeń. Nieruchomy podmiot poznający (badacz) poznaje nieruchomy przedmiot swoich zainteresowań (rzeczywistość społeczno-kulturową), reprodukując w ten sposób postkartezjańskie tradycje teoretyczno-epistemologiczne (Tatarkiewicz 1999, s. 45-57; Doy 2005, s. 1-10). W jakimś sensie można twierdzić, że taka sztuczna wizja życia społecznego i jego badania jest próbą powtarzania laboratoryjnych warunków eksperymentalnych w naukach przyrodniczych.

Współczesne badania społeczne coraz częściej jednak odnoszą się do paradygmatu mobilności (Scheller, Urry 2006), opartego na dwóch głównych założeniach. Po pierwsze, rozwój szeroko rozumianych technologii komunikacyjnych (zarówno systemu transportowego, jak i sposobów przekazywania informacji) skutkuje powstaniem nowych form koordynowania zachowań ludzi, przebiegu wydarzeń i funkcjonowania aktorów pozaludzkich (zwierząt, przedmiotów, pieniędzy itp.). Po drugie, miejsca przestają być postrzegane jako wyizolowanie elementy przestrzeni, lecz zostają połączone w rozbudowane 
sieci, stając się tym samym układem wzajemnie od siebie uzależnionych elementów. W praktyce oznacza to, że nauki społeczne zmieniają nieco szczegółowe obszary swych zainteresowań: rozwój różnego rodzaju migracji sprawia, że czymś naturalnym staje się myślenie o zmianie miejsca zamieszkania i pracy w cyklu kilkuletnim; rozwój infrastruktury transportowej skutkuje spędzaniem coraz większej ilości czasu w drodze, a podróż staje się ciekawym i ważnym obszarem badań socjologicznych; dynamika i ruch są traktowane jako podstawowe elementy konstytuujące kulturę kapitalistyczno-konsumpcyjną.

Paradygmat mobilności zachęca również do modyfikacji myślenia teoretycznego w naukach społecznych. Pojęcie płynnej nowoczesności (Bauman 2006) metaforycznie podkreśla niestałość rzeczywistości społecznej. Efemeryczność praktyk społecznych wynika również z ich oderwania od jednej skonkretyzowanej lokalizacji. Koncepcja późnej nowoczesności Anthony’ego Giddensa (2006) wskazuje, że na współczesne procesy społeczne wpływ ma mobilność nie tylko ludzi, ale również informacji, obrazów czy znaczeń. W ten sposób możliwe staje się nowe podejście do wytłumaczenia najważniejszych współczesnych zjawisk społecznych. Globalizacja może być opisywana również jako forma mobilności materiałów, co znajduje przejaw na przykład w kosmopolityzacji smaków w różnych regionach geograficznych (Sheller, Urry 2006, s. 207-208). W tym ujęciu koncepcje mobilności zbliżają się do wyjaśniania współczesnego życia społecznego z perspektywy sieci społecznych, opartej na założeniu krążenia pomiędzy węzłami tej sieci różnego rodzaju dóbr (Castells 2013; Stalder 2012).

Jeśli uznamy za fakt duże znaczenie mobilności we współczesnym świecie, to konieczne staje się uwzględnienie jego skutków na poziomie wnioskowania i zbierania danych empirycznych. Oznacza to odejście od założenia o „nieruchomym postrzegającym” (static perceiver; Ingold 2000, s. 166). Zarówno ludzie, jak i zwierzęta postrzegają świat przede wszystkim będąc $w$ ruchu, a nie tylko w wtedy, gdy są nieruchomi. Warunkiem poznania i zdobywania wiedzy jest przemieszanie się z miejsca na miejsce.

Dlatego zamierzam tu skoncentrować się na metodologicznych aspektach badań społecznych miasta w perspektywie mobilności. Mobilność jest oczywiście cechą charakterystyczną życia społecznego w każdej przestrzeni - przemieszczać można się niemal wszędzie. Może zostać zastosowana jako odniesienie teoretyczne i metodologiczne w ten sam sposób wobec innych, pozamiejskich przestrzeni. Ale to właśnie w przestrzeni miejskiej staje się ona szczególnie ważna, co najmniej z trzech powodów (Rogowski 2015). Po pierwsze, perspektywa mobilności staje się współcześnie jednym z kluczowych sposobów doświadczania miasta (Rewers 2005, s. 61-69). Wpasowuje się ona w postrzeganie miasta jako rytmicznego organizmu, odchodząc tym samym od koncentracji na dyskursywno-wizualnych aspektach przestrzeni miejskiej i traktowaniu miasta jako spektaklu. Dzieje się tak ze względu na wzrastanie złożoności życia miejskiego, o wiele większe niż w przestrzeniach innego typu. Co za tym 
idzie, po drugie, skoncentrowanie na mobilności i rytmie pozwala na odkrycie nowych form zróżnicowania życia miejskiego, rzadziej występujących gdzie indziej (Meyer 2008). Dotyczy to na przykład chronobiologii (zmienności funkcjonowania miasta w zależności od czasu i funkcjonowania organizmu ludzkiego), ścierania się ze sobą porządków naturalnego i socjoekonomicznego czy wielości oferowanych przez przestrzeń miejską bodźców. W ten sposób, paradoksalnie, nabierają znaczenia także punkty nieruchome, na przykład pomniki, które zaczynają funkcjonować jako punkty odniesienia i sposoby kształtowania orientacji w przestrzeni miejskiej (Brighenti 2010, s. 141). Po trzecie, współczesne miasto jak żadna inna przestrzeń funkcjonuje jako wielonarodowa sieć komunikacji (Stalder 2012; Burgin 1996, s. 32-33). Oznacza to szeroko rozumianą mobilność, bardziej intensywną w mieście ze względu na rozbudowaną infrastrukturę wspierającą przemieszczanie się w różnych formach.

Punktem wyjścia jest więc założenie o szeroko rozumianej mobilności jako specyficznej cesze życia w ponowoczesnym mieście. Wyznacza ona również różnicę między społeczno-kulturowym funkcjonowaniem przestrzeni w mieście i poza nim. Przyjęcie takiego założenia powinno pociągać za sobą stopniowe wprowadzanie nowych sposobów realizowania badań i analizowania zebranych za ich pośrednictwem danych empirycznych. Odniesieniem dla dalszych rozważań będzie projekt badawczy, w którym zastosowano technikę wideozwiedzania.

\section{PRZEMIESZCZANIE SIE JAKO KONTEKST DOŚWIADCZANIA PRZESTRZENI MIEJSKIEJ}

Powstanie i rozpowszechnienie się paradygmatu mobilności nie byłoby możliwe bez wcześniejszego z wrotu przestrzen nego (spatial turn) w naukach społecznych (Bachmann-Medick 2012, s. 335-389). Sprawił on, że przestrzeń przestała być traktowana przez badaczy wyłącznie jako element fizyczny, a zaczęto ją postrzegać jako wytwór życia społecznego, który zwrotnie na nie oddziałuje. Innymi słowy, przestrzeń to już nie tylko statyczny obszar, na którym dzieje się życie społeczne, lecz podmiot, z którym ludzie mogą wchodzić w dynamiczne relacje (Jones i in. 2008, s. 2). Uwzględnienie relacyjnych związków człowieka i przestrzeni skutkuje stopniowym odchodzeniem od dominującej dotychczas perspektywy danych geograficznych. Poznanie przestrzeni wymaga przebywania w niej i podejmowania tam społecznej aktywności. W ten sposób następuje przemiana uniwersalnej, anonimowej i pozbawionej indywidualnych znaczeń przestrzeni w skonkretyzowane miejsce, mające własną tożsamość i przypisywane mu przez użytkowników znaczenia (por. Rost, Cramer, Holmquist 2011; Mills, Comber, Kelly 2013).

To właśnie mobilność staje się podstawowym kontekstem przemiany przestrzeni w miejsce, w szczególności mobilność rozumiana jako przemieszczanie się - a więc taka, która jest traktowana jako codzienna i powtarzalna praktyka 
społeczna, a nie wyjątkowy i rzadki element doświadczenia. Można wskazać wiele form przemieszczania się: chodzenie, jeżdżenie na rowerze, jazdę samochodem czy komunikacją miejską. Istnieją również opracowania dotyczące wybranych form przemieszczania się (np. pielgrzymki) albo mobilności specyficznych kategorii osób (np. osób z niepełnosprawnością ruchową). Jednak na poziomie refleksji teoretyczno-metodologicznej szczególną uwagę przypisuje się do chodzenia jako formy przemieszczania się. Chodzenie można być wskazane jako przykład wytwarzania miejsca (place making), w pewnej kontrze wobec szerszego rozumienia miejsca jako wydarzenia (place-event) (Pink, Leder Mackley 2012, s. 8-9). Różnice między tymi dwoma sposobami ujmowania miejsca są związane $z$ nieco innym postrzeganiem roli ludzi i zakresu ich sprawstwa. Miejsce jako wydarzenie to skrzyżowanie procesów społecznych, przedmiotów i ludzi. Dostarcza ono ludzkim aktorom względnie stałego zestawu znaczeń, rekwizytów i podpowiedzi dotyczących łączenia ich ze sobą. Z kolei wytwarzanie miejsca stawia człowieka $\mathrm{w}$ centrum, oferując mu możliwości podmiotowego łączenia materialnych, zmysłowych i społecznych elementów miejsca. Można wskazać trzy konteksty, w których chodzenie zostaje połączone z wytwarzaniem miejsca.

Po pierwsze, chodzenie, związane jest z pewnym „zanurzeniem” się w przestrzeń. Doskonale pisze o tym Michel de Certeau (2008, s. 93-110). Wchodząc w miasto doświadczam go inaczej niż wtedy, gdy o nim piszę, myślę czy opowiadam. Również inaczej niż gdy je oglądam - zarówno bezpośrednio, jak i poprzez jego wizualne reprezentacje. Chodzenie po mieście umożliwia porzucenie racjonalnego i utopijnego dyskursu, który przejawia się w eliminowaniu odmienności, w wytwarzaniu „nie-czasu” i w „anonimizacji” uczestników życia miejskiego. Zanurzenie jest bowiem związane $z$ wykorzystywaniem wielozmysłowego doświadczenia i poznania.

Po drugie, chodzenie jest sposobem wytwarzania wspólnotowości, lecz nie według klasycznie rozumianych kryteriów wyodrębniania grup czy więzi społecznych. Chodzi tu raczej o wspólnotowość rozumianą jako współodczuwanie. Związane jest to z założeniem, że przemieszczanie się, w szczególności chodzenie, jest nie tylko sposobem zmiany miejsca pobytu, ale również pewną specyficzną formą bycia w świecie. „Myślimy stopami” (Bødker 2014, s. 4), czyli doświadczamy przestrzeni w odmienny sposób. Sposób doświadczania przestrzeni miejskiej może być różny w zależności od podłoża czy obuwia — a tym samym może wytwarzać na przykład genderowe lub generacyjne sposoby i różnice w doświadczaniu miasta. Dlatego też wspólne chodzenie, spacerowanie obok siebie, może być potraktowane jako forma wytwarzania wspólnych doświadczeń dotyczących jakiegoś miejsca. Takie współprzebywanie zaczyna wytwarzać również „wiedzę współcielesną” (body-to-body knowledge; Postma 2006, s. 326), czyli związaną z faktem, że ciała różnych osób muszą się wzajemnie do siebie dopasowywać, gdy mamy do czynienia z ruchem, rytmem, dynamiką doświadczania przestrzeni, na przykład w trakcie spacerowania. 
Co za tym idzie, po trzecie, chodzenie umożliwia zrozumienie wielości sposobów doświadczania przestrzeni. Statyczność może wytwarzać poczucie uniwersalności własnych doświadczeń, a przemieszczanie się skutkuje w jakimś stopniu ciągłym wystawieniem się na nowe wrażenia i bodźce. Nie chodzi tu jednak, oczywiście, wyłącznie o poszerzenie zakresu własnej wiedzy i doświadczeń, lecz raczej o kształtowanie w ten sposób przekładalności perspektyw. Według Sary Pink (2010) dzieje się tak głównie w toku praktyk chodzenia i dzięki wykorzystywaniu w nich poznania oraz doświadczenia wielozmysłowego. Aczkolwiek można przyjąć, że podobne są rezultaty innych form mobilności, na przykład tańca, walki czy clubbingu (Howes 2010). Przekładalność perspektyw może się odnosić zarówno do uczestników życia społecznego, mieszkańców miasta, jak i do sytuacji procesu badawczego i relacji między badaczem a badanym. Dodatkowe konteksty dają niejako szansę upewniania się, że różne strony procesu badawczego dobrze się zrozumiały. Jednocześnie wytwarzają się między nimi swoiste wspólne światy społeczne, co opiera się już nie tylko na rozmowie i oglądaniu, lecz również na wspólnym chodzeniu, na wspólnych doświadczeniach węchowych/smakowych/dotykowych, na wspólnym doświadczaniu przestrzeni czy ciała.

Opisane zależności sprawiają, że możliwe staje się badawcze łączenie przestrzeni z innymi kontekstami życia społecznego. Na przykład przestrzenne konstruowanie biografii (Kusenbach 2003, s. 478), która różni się od tradycyjnie rozumianej biografii chronologicznej tym, że punktem odniesienia stają się w niej nie tylko czas, ale również miejsca - najlepiej takie, które są aktualnie odwiedzane, lecz również takie, o których się rozmawia lub myśli. W ten sposób pamięć - zarówno indywidualna, jak i społeczna — przestaje być determinowana jedynie przez upływ czasu. Przestrzeń miejska, ze względu na zróżnicowanie i wielość oferowanych bodźców, jest szczególnie przydatna podczas przestrzennego tworzenia biografii. Kluczowe dla rozpatrywanego zagadnienia są wspomniane już pokrótce relacje między doświadczaniem przestrzeni, poruszaniem się w niej a jej oglądaniem. Jak bowiem stwierdza Henri Lefebvre (zob. Emmel, Clark 2009), przestrzeń nigdy nie może zostać pokazana przez samą siebie - ma bardzo niewielki potencjał pełnienia funkcji reprezentowania. Można o niej opowiadać, można ją opisywać lub pokazywać — w każdym $z$ tych systemów reprezentacji i komunikacji uwypuklając oczywiście nieco inne jej aspekty. Jednak w momencie wejścia w przestrzeń i bezpośredniego jej doświadczenia zaczyna oddziaływać zmysłowość, cielesność, emocjonalność i mobilność.

Przedstawiony tutaj model teoretyczny ma szczególny charakter. Nawiązuje bowiem do flaneurowskiego doświadczania przestrzeni miejskiej, znanego $z$ tradycji badawczej proponowanej niegdyś choćby przez Georga Simmla (2006) czy Waltera Benjamina (2010). Z pewnością nieco inne jest doświadczenie przemieszczania się po mieście dla tych, dla których przestrzeń miejska to miejsce pracy (taksówkarze, prostytutki, żebracy, sprzątający). W praktyce 
badawczej konieczne jest więc usytuowanie przyjętych założeń teoretycznych w szerszym kontekście metodologicznym. Dzieje się tak w podejściu określanym jako badania społeczne w ruchu.

\section{BADANIA SPOŁECZNE W RUCHU}

Punktem wyjścia do badań społecznych w ruchu (BSR) są ograniczenia związane $z$ wykorzystywaniem bardziej tradycyjnych technik badawczych: obserwacji uczestniczącej i wywiadów jakościowych. Ograniczenia te nie mają charakteru uniwersalnego. Są one szczególnie znaczące w kontekście wybranych obszarów tematycznych - w tym przede wszystkim badania społeczno-kulturowych aspektów przestrzeni. $Z$ drugiej strony, tradycyjne techniki badawcze są również powiązane $z$ określonymi założeniami teoretycznymi i wynikającym $z$ nich przebiegiem badań, na przykład wywiad narracyjny odnosi się raczej do chronologicznego sposobu rozumienia biografii i pamięci.

W najszerszym znaczeniu BSR mogą zostać potraktowane jako rodzaj obserwacji uczestniczącej (Emmel, Clark 2009, s. 9). Motywy korzystania z obu form badań (np. zintegrowanie zachowania z jego kontekstem fizycznym i przestrzennym; badanie zachowań, które nie są zapamiętywane; bardziej intuicyjny sposób zbierania danych; Guest, Namey, Mitchell 2013, s. 80-81) często są podobne i się pokrywają. Można jednak wskazać co najmniej dwa ograniczenia zastosowania obserwacji w badaniach przestrzeni miejskiej. Jest to, po pierwsze, mimo wszystko pewne „oddalenie” badacza od przestrzeni. Nawet $\mathrm{w}$ przypadku obserwacji uczestniczącej zanurzenie w przestrzeni, wytwarzanie wspólnotowości, przekładalność perspektyw mogą napotykać pewne ograniczenia. Wynika to $z$ faktu, że niektóre czynności nie są realizowane wspólnie, a brak interakcji, a tym samym cielesnego dostosowywania się uczestników usytuowanych zachowań, skutkuje innym doświadczaniem przestrzeni niż choćby w przypadku wspólnego spacerowania. Co za tym idzie, po drugie, dochodzi kwestia intersubiektywnego zrozumienia aktywności podejmowanych przez innych. Brak sytuacji wspólnego przemieszczania się w przestrzeni ogranicza intersubiektywny potencjał sytuacji badawczej.

Ten ostatni problem częściowo może zostać rozwiązany w toku wywiadów jakościowych. Aczkolwiek w takim przypadku sytuacja badawcza zostaje „zdelokalizowana”. Przestrzeń staje się elementem rozmowy, ale wobec braku faktycznej i aktualnej obecności w niej nie funkcjonuje jako „uczestnik” sytuacji badawczej. Wywiad opiera się na wspomnieniach i wyobrażeniach związanych z miastem i jego miejscami. Odnosi się więc raczej do pewnych wtórnie przetworzonych konstruktów. Pewnym rozwiązaniem jest włączenie do sytuacji wywiadu zdjęć i skorzystanie z potencjału wywiadu fotograficznego (photo-elicitation interview). W takim przypadku jednak przestrzeń, jakkolwiek wizualnie uobecniona, zostaje sprowadzona do swej dwuwymiarowej reprezenta- 
cji. Wciąż nieobecne są elementy związane $z$ wielozmysłowością, ruchem i rytmem, cielesnością, współprzebywaniem.

Podstawowym sposobem poradzenia sobie $z$ tymi problemami jest zastosowanie techniki badawczej wywiadu podążającego (go-along interview). Można go zdefiniować jako „formę pogłębionego wywiadu jakościowego, który - jak wskazuje nazwa - jest przeprowadzany przez badacza towarzyszącego badanym w trakcie wycieczek po znanym im środowisku, takim jak sąsiedztwo lub szerszy lokalny obszar" (Carpiano 2009, s. 264). Innymi słowy, wywiad podążający to sytuacja wspólnego przemieszczania się przez badacza i badanego po jakimś obszarze. W trakcie takiego spaceru badany opowiada badaczowi o swoich doświadczeniach wspomnieniach i skojarzeniach związanych z obszarem, na którym się znajduje.

Wywiad podążający ma więc cechy zarówno tradycyjnego wywiadu, jak i obserwacji uczestniczącej. W trakcie spaceru badacz może dopytywać badanego o szczególnie interesujące tematy, korzystając przy tym z mniej lub bardziej ustrukturyzowanego scenariusza wywiadu. Jednocześnie może obserwować odwiedzane miejsca i zbierać w ten sposób dane niezależnie od prowadzonej rozmowy ${ }^{1}$. Co więcej, badany może wskazywać badaczowi szczególnie istotne dla tematu miejsca i sytuacje. Wartością dodaną tych technik jest zarówno fizyczne przebywanie $\mathrm{w}$ jakiejś przestrzeni, jak i sam fakt wspólnego poruszania się. W ten sposób o wiele łatwiej można odnieść się do wspomnianych wcześniej procesów przemieniających przestrzeń w miejsce.

Założeniem wywiadu podążającego jest chęć dostosowania sytuacji badawczej do najczęściej podejmowanych przez badanych sposobów przebywania i poruszania się w przestrzeni. Dzięki temu wywiad staje się podobny do najbardziej powszechnych, a tym samym najlepiej znanych przez badanego sposobów doświadczania przestrzeni. Na tej podstawie wyróżniane są podstawowe odmiany wywiadów podążających (Kusenbach 2003, s. 464): walk-along, czyli najczęściej stosowana forma, polegająca na wspólnym chodzeniu, oraz ride-along, czyli wykorzystanie do przemieszczania się pojazdów (mogą to być zarówno samochody, autobusy/tramwaje, jak i rowery - w zależności od tego, jak najczęściej porusza się badany). W tych przypadkach szczegóły sytuacji badawczej są dość elastyczne, na przykład badany może być zarówno kierowcą, jak i pasażerem samochodu. Poza tymi najczęstszymi odmianami wywiadów podążających niekiedy realizowane są również inne, dostosowane do szczególnych sposobów przemieszczania się badanych ${ }^{2}$.

\footnotetext{
${ }^{1}$ Wykonywanie przez badacza notatek w trakcie spaceru może być traktowane jako dążenie do komplementarności różnych form komunikacji (Carpiano 2009, s. 270).

${ }^{2} \mathrm{Na}$ przykład wywiad w trakcie spaceru z psem (Cameron i in. 2014). Im bardziej niestandardowa forma przemieszczania się, tym trudniejsza ze względu na nieprzewidywalność zachowań może być realizacja wywiadu.
} 
Inna klasyfikacja wywiadów podążających opiera się na sposobach wyznaczania trasy (Emmel, Clark 2009, s. 13-14). Walk-alongs to wówczas przechadzki po terenach i obszarach dobrze znanych badanemu. Ich przebieg jest w mniejszym stopniu zaplanowany i w głównej mierze zależy od skojarzeń i podejmowanych na bieżąco decyzji uczestników badań. Można też mówić o node-to-node walk, czyli przechadzkach bardziej zaplanowanych, z założenia uwzględniających bądź punkty początkowe, bądź całą trasę, po które będą się przemieszczać uczestnicy. Taka zestandaryzowana forma spaceru pozwala później uniknąć wielu problemów przy porównywaniu konkretnych przypadków, lecz jednocześnie $\mathrm{w}$ jakimś stopniu tłamsi kreatywność badanych i niestandardowość ich skojarzeń/doświadczeń. Trzecia odmiana to extended journeys. Obejmują one spory obszar i $z$ tego powodu wymagają przemieszczania się za pośrednictwem różnych form transportu. Może to być na przykład spacer, następnie przejazd samochodem do innego miejsca i kolejny spacer ${ }^{3}$.

Wspólna obecność w przestrzeni badacza i badanego najczęściej jest elementem korzystnym dla obu stron procesu badawczego. Dowartościowana zostaje rola badanego. Zaczyna być on traktowany jako „lokalny ekspert” (Clark, Emmel 2010, s. 4), który zauważa, że jego doświadczenia są dla kogoś ważne i interesujące. Dzięki temu może w większym stopniu odkrywać się przed badaczem i dzielić się z nim kolejnymi skojarzeniami i wspomnieniami. Jednocześnie badany to również „przewodnik” (tour guide; Carpiano 2009, s. 267), który nie tylko oprowadza po przestrzeni, ale także uprawomocnia odbywające się w niej aktywności badawcze. Jest to szczególnie istotne wtedy, gdy badacz planuje wielokrotną obecność w jakiejś niewielkiej przestrzeni zamieszkiwanej przez w miarę zamkniętą i spójną społeczność. Dzięki współobecności badacza i badanego fakt ten zostaje zaakceptowany przez zamieszkujących teren badawczy.

Niezależnie od oczywistych zalet badawczych technika wywiadu podążającego generuje również nowe wyzwania dla badacza. Po pierwsze, są to wyzwania logistyczne dotyczące przebiegu procesu badawczego (Cameron, Smith, Tumilty, Treharne 2014, s. 166-167). Nad niektórymi warunkami (np. pogoda) badacz nie jest w stanie sprawować kontroli, co skutkuje częstszą niż w przypadku klasycznych technik koniecznością odwoływania lub zmiany terminu badania. Zarówno pogoda, jak i pora dnia mają wpływ na przebieg oraz na sposób rejestracji wywiadu podążającego. Wyzwania logistyczne dotyczą również czasu trwania wywiadu i jego nieprzewidywalności w przypadku pozostawienia

${ }^{3}$ Warto jeszcze wspomnieć o innej tradycji BSR, w większym stopniu polegającej na ilościowym analizowaniu zachowań przechodniów w tłumie (Moussaïd i in. 2010). Dzięki nagraniom z kamer przemysłowych możliwe jest badanie takich aspektów, jak: kształt przemieszczających się grup, relacje między kształtem a gęstością grup, relacje między gęstością a szybkością przemieszczania się grup. W ten sposób następuje odejście od tematów tradycyjnie podejmowanych dzięki wywiadom podążającym, czyli percepcji, praktyk przestrzennych, biografii, społecznych aspektów architektury $\mathrm{i}$ in. (Kusenbach 2003, s. 13-24). 
badanym swobody wyboru trasy. Przy planowaniu badań bez wątpienia należy wziąć pod uwagę możliwości przemieszczania się badanych związane $\mathrm{z}$ ich zdrowiem, wiekiem lub niepełnosprawnością. Po drugie, należy wskazać również na nowe wyzwania prawne i etyczne, które pojawiają się przy przeprowadzaniu wywiadów podążających. Chodzi przede wszystkim o problem występujący we wszystkich badaniach prowadzonych w sferze publicznej lub półpublicznej — braku możliwości poinformowania o badaniach wszystkich napotkanych osób i uzyskania zgody (Guest, Namey, Mitchell 2013, s. 101-102). Wywiad podążający zawsze zmienia stosowane $\mathrm{w}$ badaniach kryteria anonimowości (Clark, Emmel 2010, s. 5). Co więcej, w przestrzeni o charakterze publicznym może być podejmowana aktywność o charakterze prywatnym. Zadaniem badacza jest taka realizacja badań, by nikomu nie wyrządzić szkody. Zakres niezbędnej uważności jest więc w tym przypadku uzależniony od sposobu rejestrowania wywiadu. Należy uwzględniać przyszłe formy komunikowania wyników badań, w tym potencjalną publiczność i zakres jej zaznajomienia $z$ tematyką badań i ich uczestnikami. Przy planowaniu badań trzeba wziąć pod uwagę także bezpieczeństwo uczestników wywiadu (Carpiano 2009, s. 270).

$\mathrm{W}$ toku dalszych rozważań będę nawiązywał do tradycji badań przeprowadzanych przy wykorzystaniu większości podstawowych założeń wywiadów podążających, uwzględniając zmianę sposobu ich rejestrowania. Nie będzie to, jak zazwyczaj w przypadku go-alongs, tradycyjne nagrywanie na dyktafon i koncentrowanie się wyłącznie na relacjach słownych, lecz zapis obrazów. Wideozwiedzanie (wideospacery, walking-with-video; Pink 2007) polega na rejestrowaniu przemieszczania się $\mathrm{w}$ sposób wizualny - powstaje w ten sposób materiał wideo. Nie jest to zmiana wyłącznie techniczna i logistyczna, określa ona bowiem potencjał badawczy. Zanim dokładniej opiszę sposoby korzystania z wideospacerów, nawiążę do pytania o miejsce wizualności, w szczególności filmu i wideo, w badaniach społecznych w ruchu.

\section{METODY WIZUALNE W BADANIACH SPOŁECZNYCH W RUCHU}

Jeżeli jednocześnie stosujemy BSR i metody wizualne, to wiele większy potencjał oferują obrazy ruchome, czyli wideo i filmy. Zdjęcia - jako obrazy statyczne - mogą kolidować $z$ dynamiczną naturą BSR - zarówno jeśli chodzi o ich funkcję komunikacyjną (zdjęcia jako ilustracja wypowiedzi badanych), jak i funkcję wyzwalającą (wykonane w trakcie spaceru zdjęcie jako element wywołujący wypowiedzi w późniejszych wywiadach fotograficznych). Choć oczywiście, jeśli nie ma innej możliwości, warto je wykorzystać jako element stymulujący wyobrażenia o przestrzeni i mobilności. Nieco inny może być status map i rysunków w badaniach w ruchu. W szczególności chodzi tutaj o mapy mentalne, czyli rysowane z lotu ptaka wyobrażenia o danej przestrzeni (Lynch 1990). Takie materiały mogą być efektywnie wykorzystane zarówno jako wstęp, jak $\mathrm{i}$ jako podsumowanie badań $\mathrm{w}$ ruchu, a dane $\mathrm{z}$ obu tych etapów mogą wza- 
jemnie się uzupełniać. Tutaj skoncentruję się jednak na wykorzystaniu w BSR filmu i wideo.

Materiały wizualne wykorzystywane w BSR można podzielić ze względu na ich autorstwo (DuFon 2002, s. 52-55). Po pierwsze, może to być autorstwo badacza - gdy jednocześnie prowadzi on rozmowę i kontroluje kamerę. W takim przypadku mniej osób jest zaangażowanych w działania badawcze, a badacz ma możliwość sprawowania większej kontroli nad badaniem. Jednak wykonywanie innych czynności (rozmowa, robienie notatek) jest wtedy częściowo utrudnione. Pewnym rozwiązaniem może być zastosowanie kamery GoPro, która nie zajmuje rąk badacza i w procesie badawczym jest stosunkowo mało inwazyjna. Po drugie, materiały wizualne mogą być sporządzone przez profesjonalnego filmowca. Można wówczas liczyć na większe doświadczenie ich twórcy, a tym samym na ich lepszą jakość końcową. Włączenie do uczestników sytuacji badawczej kolejnej osoby zwiększa też elastyczność działań badacza. Jednakże dotychczasowe przyzwyczajenia z pracy z filmem mogą być inne u badacza i u filmowca, a tym samym uzyskany materiał może nie spełniać oczekiwań zespołu badawczego. W szczególności może to dotyczyć szczególnej koncentracji filmowca na aspektach artystycznych. Zatrudnienie specjalisty może też zwiększać koszty — zarówno finansowe i logistyczne, jak i emocjonalne. Obecność filmowca - osoby z zewnątrz, nieznanej wcześniej i często dla badanego anonimowej - może niszczyć intymny charakter spaceru i wzbudzać dodatkowe obawy. Dlatego jeśli decydujemy się na skorzystanie z pomocy profesjonalisty, musimy najpierw zaznajomić z nim badanego i wytłumaczyć powody naszego postępowania, gdyż niespodziewana obecność kamery i obsługującej ją osoby może być zbyt paraliżująca. Po trzecie, autorem materiałów wizualnych może być sam badany. Jest to wskazane zwłaszcza wtedy, gdy pochodzi on $z$ odmiennych grup kulturowych niż badacz. Co więcej, przekazanie apara$\mathrm{tu} /$ kamery badanemu jest swoistym przypomnieniem o tym, że reprezentacje są aktualnie wytwarzane (Bean 2008, s. 108). Wykonywanie materiałów wizualnych przez badanych napotyka te same problemy logistyczno-organizacyjne, jakie towarzyszą filmowaniu przez badacza.

Drugim kryterium podziału materiałów wizualnych w BSR jest pytanie o to, kto powinien znaleźć się na filmie. Jest to również powiązane $z$ celem, jaki stawiamy sobie $\mathrm{w}$ badaniach, a także funkcją, jaką chcemy przypisać materiałom wizualnym (DuFin 2002, s. 49-52). Z uwagi na to kryterium można wyróżnić trzy kategorie filmów. Po pierwsze, film obserwacyjny, nastawiony na pokazanie jakiegoś wycinka rzeczywistości społecznej. Badacz i filmowiec nie są w tym przypadku obecni w kadrze. Taki rodzaj rejestracji jest mniej użyteczny dla BSR, można go potraktować raczej jako formę obserwacji i analizy interakcji w przestrzeni. Po drugie, film partycypacyjny — jego twórca koncentruje się zarówno na produkcie końcowym, jak i na jego wytwórcach. Istnieje więc możliwość zobaczenia na filmie badacza, badanych, filmowca. Partycypacja jest więc rozumiana jako swoista podwójność ról: zarówno uczestnika badania, jak i póź- 
niej osoby występującej w finalnym materiale audiowizualnym. Trzeci rodzaj to film refleksyjny. Zawiera on częściowo cechy dwóch pierwszych, lecz ponadto koncentruje się na procesie wytwarzania. Związane jest to z założeniem, że rezultat końcowy jest uzależniony od sposobu powstawania. Film refleksyjny jest najbardziej użyteczny w BSR. Uwzględnia bowiem to, że sam fakt i świadomość rejestrowania audiowizualnego wyzwala nowe sposoby zachowań i nowe formy refleksji.

Badacze wykorzystujący film i wideo w badaniach społecznych, w tym w BSR, wskazują zarówno wady, jak i zalety obecności tego medium w procesie badawczym. Zalety podpowiadają w przypadku jakich działań i obszarów badawczych warto skorzystać z materiałów wizualnych, a wady stają się wyzwaniem, gdy już zdecydowaliśmy się skorzystać $\mathrm{z}$ filmu/wideo $\mathrm{w}$ badaniach.

Wskazywane zalety odnoszą się zazwyczaj do przedstawianych tu już podstawowych założeń teoretycznych i epistemologicznych dotyczących badania przestrzeni i badań w ruchu (Pink 2006, s. 41-58; Mills, Comber, Kelly 2013; Pink, Leder Mackley 2012; Heath, Hindmarsh 2002; Parkin, Coomber 2009). Wskazują na rozszerzanie możliwości eksplanacyjnych i komunikacyjnych badań społecznych. Przede wszystkim chodzi tu o potencjał aktywizowania za pośrednictwem materiałów wizualnych różnych aspektów doświadczenia, również tych związanych ze zmysłowością, cielesnością i emocjonalnością. Dotyczy to dwóch aspektów. Z jednej strony sama obecność kamery i świadomość bycia rejestrowanym audiowizualnie skłania badanych do większego zaangażowania cielesno-emocjonalnego w nagranie. Chęć odgrywania emocji i większego dramatyzowania swoich zachowań — skutkuje większym odczuwaniem własnych emocji i głębszym doświadczeniem wielozmysłowym (aczkolwiek będzie to za chwilę opisane również jako potencjalna wada). Z drugiej strony nagranie audiowizualne stwarza większe możliwości późniejszego opowiedzenia o doświadczeniach wielozmysłowych ${ }^{4}$. Wynika to $z$ możliwości zastosowania narzędzi filmowych - kadrowania, zbliżeń, pauz - które uwypuklają takie doświadczenia.

Jeśli chodzi o wady/wyzwania, to wskazuje się przede wszystkim różnego rodzaju wątpliwości dotyczące wiarygodności zapisu wideo (Henley 2005; Pasqualino 2007; DuFon 2002). Kamera może wywołać u badanych specyficzne zachowania. Świadomość bycia filmowanym zachęca do swoistego performansu: utraty spontaniczności, dramatyzowania gestów. Wiarygodność może być zaburzona również ze względu na szeroko rozumiany kontekst: prezentowanych miejsc i wydarzeń, sposobu edytowania i montowania, a także klasycznego dla materiałów wizualnych problemu, czyli kadrowania. W trakcie badań nie ma możliwości zarejestrowania wszystkiego, co jest obserwowalne, a wybór tego, co znajduje się w kadrze, jest elementem wpływającym na późniejszą war-

${ }^{4}$ Aczkolwiek wskazuje się, że wzbudzane w odbiorcach odczucia zmysłowe mogą różnić się od tych, które były doświadczane przez uczestników sfilmowanej sytuacji. 
tość empiryczną wideo. Wiarygodność dotyczy w końcu pytania o powszechność lub wyjątkowość prezentowanych sytuacji.

\section{WIDEOZWIEDZANIE JAKO TECHNIKA BADAWCZA}

Doświadczenia badawcze związane z miejskimi BSR przedstawię na przykładzie projektu „Strefa Święty Marcin”, koordynowanego przez Centrum Kultury Zamek w Poznaniu. Projekt był realizowany w Poznaniu w latach 2013-2014, polegał na szeregu działań poświęconych tematyce rewitalizacji ulicy Święty Marcin w Poznaniu. Jest to jedna z głównych ulic miasta, prowadząca w przybliżeniu od Ronda Kaponiera do Starego Rynku. Przy Świętym Marcinie znajduje się wiele istotnych historycznie i społecznie obiektów, między innymi Zamek Cesarski, były Komitet Wojewódzki PZPR czy Pomnik Poznańskiego Czerwca 1956 (tzw. Poznańskie Krzyże). Jeszcze w latach dziewięćdziesiątych XX wieku ulica pełniła ważne funkcje społeczne, komunikacyjne i handlowe, jednak od około dwudziestu lat można zauważyć jej stopniowe podupadanie.

W ramach „Strefy Święty Marcin” podjęto szereg interdyscyplinarnych aktywności: debat, warsztatów, działań artystycznych. Jednym z kluczowych elementów projektu były badania empiryczne realizowane wspólnie przez Centrum Kultury Zamek i Instytut Socjologii Uniwersytetu im. Adama Mickiewicza w Poznaniu. Ich najważniejszy element stanowiły opisane niżej wideospacery. Przeprowadzono również, przy współpracy poznańskiej „Gazety Wyborczej”, konsultacje społeczne dotyczące projektów zmian na ulicy Święty Marcin.

Od kwietnia 2013 roku do listopada 2014 roku zrealizowano 24 wideospacery. Uczestniczyli w nich przedstawiciele różnych kategorii mieszkańców Poznania: mieszkańcy ulicy Święty Marcin, właściciele lokali użytkowych przy tej ulicy oraz eksperci (dziennikarze, artyści, historycy sztuki, lokalni politycy). Dobór badanych miał charakter celowy i częściowo polegał na wykorzystaniu metody kuli śnieżnej. Wszystkie spacery były rejestrowane audiowizualnie, następnie zmontowano filmy, a część z nich została publicznie zaprezentowana.

Doświadczenia związane $z$ badaniem przestrzeni miejskiej $z$ wykorzystaniem techniki badawczej wideozwiedzania dotyczą trzech głównych etapów badania: przygotowania, realizacji oraz opracowania i komunikowania. Opis tych doświadczeń, który może zostać potraktowany jako etnografia procesu badawczego, odnoszę do wspomnianych wcześniej założeń i dylematów związanych z BSR i wykorzystaniem w nich materiałów wizualnych.

\section{Przygotowanie}

Pierwsza decyzja, którą należało podjąć w projekcie, dotyczyła tego, w jaki sposób i przez kogo będą nagrywane materiały wizualne. Oczywiście można w badaniach łączyć różne sposoby rejestrowania audiowizualnego, ale ich zestandaryzowanie ułatwia późniejszą analizę zebranego materiału. Zdecydo- 
waliśmy się na nagrania realizowane przez profesjonalnych filmowców, ponieważ w zamyśle zebrane materiały miały być również publicznie prezentowane. $Z$ tego powodu zagwarantowanie możliwie wysokiej jakości technicznej i estetycznej było istotne. Ponadto wideozwiedzanie jest techniką, w której zarówno badacz, jak i badany powinni być widoczni na nagraniu wideo.

Umawianie się z badanymi na spacer odbywało się telefonicznie bądź osobiście. Osobisty kontakt jest wskazany w przypadku tych osób, które nie są zaznajomione $z$ sytuacją bycia filmowanym (zazwyczaj były to osoby starsze i nie-eksperci). W trakcie rozmowy wstępnej przedstawiana była idea badań — ich cel oraz oczekiwany sposób postępowania w trakcie spaceru. Informowaliśmy, że badania mają na celu poznanie historii, wspomnień i doświadczeń związanych $z$ ulicą oraz opinii na temat jej obecnego stanu i funkcjonowania. Podkreślaliśmy, że nie oczekujemy od badanych informacji „encyklopedycznych”, czyli takich, które należą do oficjalnej i znanej wielu historii i które można odnaleźć w książkach lub w internecie. Wskazywaliśmy raczej na chęć poznania osobistych doświadczeń, nawet takich, które mogą się wydawać banalne i mało znaczące. Informowaliśmy również o tym, że spacer będzie rejestrowany kamerą wideo. Na koniec wstępnego spotkania/rozmowy umawialiśmy się na dokładny termin spaceru i miejsce spotkania. Fakt zaangażowania filmowca skutkował tym, że konieczne było skoordynowanie terminarzy co najmniej trzech osób, co niekiedy mogło sprawiać trudności. Najczęściej jako miejsce spotkania przed spacerem ustalaliśmy Centrum Kultury Zamek przy ulicy Święty Marcin. Trzeba jednak pamiętać, aby takiego miejsca nie narzucać odgórnie, gdyż początek spaceru decyduje o jego dalszym przebiegu. W kilku przypadkach miejsce rozpoczęcia spaceru było więc inne ze względu na decyzję badanego. Między spotkaniem lub rozmową wstępną a spacerem ubiegało zazwyczaj nie więcej czasu niż tydzień. Dzień przed spacerem ustalony wcześnie termin był potwierdzany telefonicznie.

Przed spacerem konieczne było podpisanie $z$ badanym umowy. Ze względu na fakt rejestracji audiowizualnej powinna ona zawierać zgodę na udostępnianie własnego wizerunku ${ }^{5}$. Trzeba jednak pamiętać, że samo uzyskanie takiej zgody nie rozwiązuje dylematów prawno-etycznych. Całe badanie, od pierwszego kontaktu $z$ badanym aż po sposób komunikowania uzyskanego materiału, musi opierać się na zasadach świadomej zgody (informed consent). Badany musi więc mieć pełną świadomość tego, w jaki sposób uzyskane materiały będą wykorzystane, że jego wizerunek może być publicznie prezentowany i rozpowszechniany cyfrowo w różnych kontekstach. Jest to szczególnie ważne w przypadku tych osób, które w jakimś stopniu podlegają cyfrowemu wykluczeniu i mogą nie być w pełni świadome zasad funkcjonowania internetu (gdy

${ }^{5} \mathrm{~W}$ przypadku poznańskich badań udział badanych w spacerze był wynagradzany niewielką kwotą pieniężną wypłacaną na mocy umowy cywilnoprawnej, w której była zawarta również taka zgoda. 
zakłada się umieszczenie wideo w sieci). Warto również wpierw upewnić się, że badany nie będzie miał żadnych problemów związanych z uczestnictwem $\mathrm{w}$ spacerze (np. nie będzie $z$ tego powodu pretensji ze strony społeczności lokalnej, sąsiadów, rodziny).

Przed spacerem istnieje również możliwość sformułowania na żywo dokładniejszych wyjaśnień technicznych. Powszechność korzystania z technologii wizualnych nie jest tu ułatwieniem, gdyż sytuacja korzystania w badaniu z kamery obsługiwanej przez profesjonalistę jest czymś całkowicie innym niż codzienne wykonywanie zdjęć czy filmów. Niekiedy nawet osoby mające bardziej profesjonalny kontakt z mediami potrzebują wcześniejszych wyjaśnień, gdyż rejestracja audiowizualna w przestrzeni publicznej jest stosunkowo rzadka. Należy więc przypomnieć badanym, żeby nie zwracali uwagi na filmowca. Sytuacja spaceru ma być w miarę swobodną rozmową, należy więc kierować swoje słowa bezpośrednio do badacza. Bezprzewodowe mikrofony rejestrujące dźwięk przypinane są do ubrania badacza i badanego, co znacznie ułatwia realizację badań, gdyż nie wymaga dodatkowych wysiłków związanych z trzymaniem większego mikrofonu w rękach. W przypadku braku możliwości skorzystania z mikrofonów bezprzewodowych można oczywiście nagrywać rozmowę na dyktafon, ale wtedy trzeba później skoordynować nagrany dźwięk z obrazem z kamery. Gorszym rozwiązaniem jest korzystanie $z$ mikrofonu umieszczonego $w$ kamerze. Zasięg nagrywania jest $\mathrm{w}$ takim przypadku zazwyczaj niewielki, przez co filmowiec musi podążać blisko spacerujących, co może negatywnie wpływać na przebieg spaceru.

W ramach przygotowań warto przypomnieć i rozszerzyć wstępne ustalenia dotyczące zasad przebiegu spaceru. W celu ułatwienia badanemu zrozumienia sytuacji można go zachęcić do wyobrażenia sobie, że badacz jest turystą, który po raz pierwszy odwiedza jakieś miejsce i jest oprowadzany po pewnej przestrzeni. W ten sposób badany uświadamia sobie, że warto mówić o sprawach nawet najbardziej oczywistych, które nie wspomniałby w rozmowie $z$ osobą lepiej znającą daną przestrzeń. Tym samym badany zaczyna być traktowany jako „ekspert codzienności”, który z jednej strony dobrze zna jakąś przestrzeń i potrafi zdecydować, co jest w niej ważne, a z drugiej koncentruje się na tym, co charakterystyczne dla życia codziennego. Dlatego dalej będę określał badanych mianem przewodników, co jest również formą upodmiotowienia ich roli $\mathrm{w}$ procesie badawczym.

\section{Realizacja}

Przebieg trasy, miejsce początkowe i końcowe oraz czas trwania spaceru zależą w dużej mierze od rodzaju przestrzeni, w której badanie jest realizowane. Wideozwiedzanie na Świętym Marcinie dotyczyło jednej ulicy, dlatego trasa zdecydowanie miała charakter linearny; badani rzadko wchodzili w boczne uliczki. $Z$ tego powodu również późniejsze porównywanie ze sobą poszcze- 
gólnych spacerów było łatwe. Inaczej wyglądają spacery wtedy, gdy badania dotyczą na przykład przestrzeni dzielnicy. Każdy może przebiegać nieco inną trasą, rozpoczynać się i kończyć w innych miejscach, a także czas jego trwania może być bardzo różny. W opisywanych badaniach czas trwania jednego spaceru wynosił zazwyczaj około godziny. Co ciekawe, na przebieg spaceru ma wpływ również ukształtowanie terenu. Ulica Święty Marcin jest nieco pochylona i opada w dół w kierunku Starego Rynku. Zapewne również z tego powodu większość badanych proponowała rozpoczęcie spaceru na Placu Adama Mickiewicza, następnie schodzono w dół ulicy i kończono spacer w okolicach Alei Marcinkowskiego i Galerii MM. Było tak, mimo że numeracja budynków rośnie w kierunku przeciwnym.

W trakcie spacerów niemal pełną inicjatywę należy oddać przewodnikowi. To on powinien decydować o tym, dokąd pójdziemy, w którym miejscu się zatrzymamy, na którym przejściu dla pieszych przejdziemy na drugą stronę ulicy. W ten sposób odnosimy się do dwóch nieformalnych sposobów strukturyzowania spaceru: przestrzeni i pamięci. Tok badania zostaje wyznaczony przez połączenie ze sobą miejsc $\mathrm{w}$ przestrzeni i skojarzeń z nimi związanych. Ta sama trasa może przywoływać całkowicie różne opowiadania, zależnie od pełnionych przez przewodnika ról społecznych, statusu rodzinnego czy kategorii społecznej. Przestrzeń również jest elementem, który aktywizuje przewodnika i zachęca do go dzielenia się swoimi doświadczeniami bardziej niż tradycyjne wywiady.

W praktyce realizacja tych założeń zależy oczywiście od otwartości przewodnika. Gdy brakuje mu inicjatywy, warto na przykład zachęcić do przejścia na drugą stronę ulicy, jeśli dotychczas pozostawano na jednej. Gdy przewodnik wypowiada się nieco dłużej na temat jakiegoś punktu w przestrzeni, warto zachęcić go do zatrzymania się na chwilę. Narracja na temat jakiegoś miejsca będzie wówczas łatwiejsza, a filmowiec będzie miał większą możliwość kadrowania. Ze strony badacza konieczne jest więc wstępne rozpoznanie otwartości i spontaniczności przewodnika i określenie na tej podstawie, w jakim stopniu należy wspomagać realizację spaceru. Może to dotyczyć również zachęty do skracania spaceru, gdy trwa on już zbyt długo.

Strukturyzowanie poprzez pamięć i przestrzeń nie oznacza, że przystępujemy do spaceru bez problematyki badawczej i bardziej szczegółowych pomysłów na tematyczny przebieg sytuacji badawczej. Na poziom spaceru przekładają się one nie $\mathrm{w}$ formie konkretnych pytań scenariusza, lecz raczej określenia obszarów tematycznych, do których warto nawiązać. W przypadku badań na Świętym Marcinie takich obszarów było kilka, między innymi: funkcje ulicy (przede wszystkim komunikacyjna i handlowa), hałas na ulicy, ikonosfera ulicy, bezpieczeństwo, punkty kluczowe i wspomnienia. Badacz powinien kontrolować, w jakim stopniu określone zagadnienia zostały poruszone. Jeżeli nie, warto do nich w pewnym momencie nawiązać, ale $\mathrm{w}$ taki sposób, by włączyć tematykę w aktualny kontekst spaceru. Na przykład do odgłosów ulicy można nawiązać 
wtedy, gdy rozmowa została na chwilę przerwana ze względu na hałas przejeżdżającego obok tramwaju; o przemieszczaniu się można mówić wtedy, gdy musimy omijać zniszczony chodnik; o funkcji handlowej wtedy, gdy przewodnik wspomina swoje ulubione sklepy z przeszłości. Nawiązywanie do wyznaczonych tematów powinno więc odbywać się w taki sposób, by przewodnik nie odniósł wrażenia, że tematyka jest mu w jakikolwiek sposób narzucana.

Dzięki takiemu postępowaniu możliwe staje się również większe uwzględnienie wielozmysłowości spaceru. Wspólne spacerowanie aktywizuje wrażenia dotyczące również dźwięków i zapachów. Można odnosić się do rytmu ulicy czy do wrażeń dotykowych związanych na przykład z podłożem. Przestrzeń ma możliwość nie tylko strukturyzowania rozmowy, ale również jej zmysłowego stymulowania. Na przykład przebywanie w pobliżu kawiarni może przypomnieć smaki związane $z$ podawanymi tam kiedyś deserami.

Przebieg spaceru w bardzo dużym stopniu zależny jest od operatora/filmowca towarzyszącego badaczowi i przewodnikowi przez cały czas trwania spaceru. Dobry operator to nie tylko taki, który ujmie dobry kadr, ale również taki, który w trakcie spaceru będzie pozostawał "niewidzialny”, czyli nie będzie ingerował w sposób przemieszczania się spacerującej pary. Po pierwsze, powinien więc zachować odpowiedni odstęp, ujmując spacer raczej w szerokim niż wąskim kadrze, gdyż w innym przypadku jego obecność mogłaby przeszkadzać $\mathrm{w}$ przemieszczaniu się. Po drugie, swoim zachowaniem i ruchem kamery nie powinien podpowiadać toku spaceru i rozmowy. Jednocześnie mimo zachowania przynajmniej dwu-trzymetrowej odległości powinien mieć możliwość słyszenia tego, o czym rozmawiają spacerujący. Najlepiej zapewnić to za pośrednictwem małej słuchawki, która podłączona do kamery przekazuje dźwięk rejestrowany przez mikrofony. Stały dostęp do treści rozmów jest potrzebny, gdyż zadaniem operatora jest filmowanie nie tylko spacerującej pary, ale również obiektów, o których jest mowa, aby późniejszy odbiorca zarejestrowanego materiału miał możliwość zobaczenia, o jaki obiekt chodzi. Cechą dobrego filmowca jest więc pewna doza elastyczności, która umożliwia mu swobodne przechodzenie między filmowaniem spacerujących a filmowaniem obiektów.

$\mathrm{W}$ trakcie spaceru mogą powstać sytuacje związane $z$ obecnością innych osób, które częściowo wpływają na przebieg badań. Sytuacja filmowania ma charakter niecodzienny, a więc w oczywisty sposób przyciąga uwagę przechodniów. Jest to jednak raczej przyglądanie się spacerującym lub oglądanie się za nimi niż wchodzenie $z$ nimi w interakcje, które pojawiają się co najwyżej wówczas, gdy przewodnik spotyka na swojej drodze kogoś znajomego. Może wtedy nastąpić krótka wymiana grzeczności. W trakcie opisywanych badań zdarzyło się, że jednej z przewodniczek towarzyszyła podczas spaceru znajoma. Pozostawała ona jednak zawsze co najmniej kilka metrów za spacerującymi i nie wchodziła $z$ nimi w interakcje. Taka sytuacja może zapewniać niektórym badanym większy komfort psychiczny i większe poczucie bezpieczeństwa, więc nie należy się jej sprzeciwiać. 


\section{Opracowanie i komunikowanie}

Rezultatem pojedynczego spaceru jest materiał audiowizualny zawierający zapis całej trasy. Taki surowy materiał może zostać przetworzony i opracowany na różne sposoby.

Po pierwsze, możliwe są analizy oparte na transkrypcjach spacerów. Błędem byłoby jednak wykonywanie transkrypcji zgodnie $z$ zasadami przyjętymi w odniesieniu do tradycyjnych wywiadów jakościowych. W takiej sytuacji - gdy całość materiału audiowizualnego zostałaby w prosty sposób przepisana słownie - zatracony zostałby w dużej mierze potencjał generowany przez przestrzeń, badania w ruchu i metody wizualne. Aby więc uwzględnić ten potencjał, należy zastosować nieco rozbudowaną formę transkrypcji, uwzględniając cztery dodatkowe elementy. Pierwszym są dane dotyczące lokalizacji poszczególnych wypowiedzi i specyfiki danego miejsca. W transkrypcji należy więc oznaczyć tę lokalizację (poprzez adres lub inną formę opisu). Drugi element to inne okoliczności wypowiedzi, które mogą wpływać na jej treść lub być przyczyną jej pojawienia się. Mogą to być roboty drogowe, gęstość tłumu przechodniów, specyficzne odgłosy lub inne wrażenia zmysłowe. Trzeci element to wskazanie na to, czy wypowiedź miała miejsce w trakcie przemieszczania się, gdyż mobilność lub statyczność przewodnika mogą być potraktowane jako wskaźnik istotności przekazywanych treści. Czwarty element to transkrypcja gestów i innych zachowań niewerbalnych. Umożliwia to uwzględnienie w jakimś stopniu emocjonalnych, cielesnych i zmysłowych aspektów spaceru.

Uwzględnienie w transkrypcji różnych kontekstów spaceru odróżnia taką formę badań od tradycyjnych wywiadów. Trzeba jednak pamiętać, że każda transkrypcja, tym bardziej odnosząca się do materiałów wizualnych, w jakimś stopniu zubaża pierwotny materiał. Jest bowiem formą tłumaczenia i przechodzenia między różnymi kodami komunikacyjnymi. Transkrypcja nagrania audiowizualnego to tłumaczenie kodu wizualno-werbalnego na kod wyłącznie werbalny. Niektóre elementy spaceru trudno przekładalne na formę pisaną mogą yatem pozostać niezauważone. Dlatego drugim sposobem opracowania pozyskanych materiałów jest łączenie transkrypcji językowych $z$ danymi o innym charakterze. $Z$ jednej strony mogą to być kadry $z$ wideo, dołączane do niektórych fragmentów transkrypcji wtedy, gdy aspekty wizualne są szczególnie istotne dla zarysowania kontekstu wypowiedzi. $Z$ drugiej strony transkrypcja może uwzględniać mapy — zarówno plany miasta pokazujące wybrane fragmenty przestrzeni, w której odbywał się spacer, jak również mapy mentalne, jeśli w badaniach zdecydowano się na ich wykorzystanie. Takie łączenie różnych rodzajów danych staje się prostsze, gdy wykorzystuje się cyfrowe, multimedialne formy opracowywania wyników badań. W takim przypadku możliwe jest również łączenie mapy $z$ fragmentami wideo lub wycinkami nagrań wypowiedzi badanych. 
Multimedialne opracowania mogą zostać potraktowane również jako forma popularyzacji wyników badań. Materiały zebrane podczas spacerów można wykorzystać na przykład jako elementy stron internetowych pełniących funkcję przewodników po jakiejś przestrzeni. Najbardziej oczywistym sposobem popularyzacji wyników badań jest oczywiście publikowanie wideo. Gdy jednak na to się zdecydujemy, trzeba pamiętać, że obejrzenie nagrania o długości około godziny będzie bardzo trudne dla przeciętnego odbiorcy. Dlatego niezbędny jest montaż, skrót całości nagrania do około dziesięciu minut. Jeśli badacz posiada odpowiednie umiejętności, a w projekcie nie uczestniczył profesjonalny filmowiec, to sam może podjąć się tego zadania. Jeśli zangażowano filmowca, lepiej jemu przekazać montaż. Istotne jest pytanie o to, kto decyduje o wyborze fragmentów. Najmniej odpowiednim rozwiązaniem jest powierzenie tego zadania filmowcowi, gdyż może on wartościować materiał według własnych kryteriów (głównie estetycznych). Lepiej, gdy sam badacz ogląda nagranie, wybiera czas odpowiednich fragmentów i realizację powierza specjaliście. Może być też tak, że badacz i przewodnik wspólnie oglądają nagranie, a o wyborze fragmentów decyduje przewodnik. Dokonywanie selekcji przez badacza jest rozwiązaniem sprawniejszym logistycznie, ale może doprowadzić do tego, że powstanie tendencja do wyboru $z$ kolejnych spacerów fragmentów wcześniej niespotykanych, a nie tych istotnych poznawczo. Co więcej, selekcja dokonana wspólnie przez badacza i przewodnika może być potraktowana jako kolejny etap badań i forma wywiadu filmowego (film-elicitation interview). Daje przewodnikowi możliwość spojrzenia na siebie, swoje wypowiedzi i zachowania $z$ innej perspektywy i odniesienia się do nich. Powstaje jednak obawa, że wybór będzie dokonywany przez przewodnika nie na podstawie istotności wypowiedzi i tematu, ale oceny własnego wizerunku.

$\mathrm{Na}$ opracowanie i sposób komunikowania wyników wpływa również to, jakie instytucje są zaangażowane w realizację badań. Projekt „Strefa Święty Marcin”, realizowany we współpracy instytucji dwóch typów - kulturalnej i naukowej, dobrze pokazał różnicę oczekiwań wobec projektów badawczych. Dla Centrum Kultury Zamek równie cenna jak wartość poznawcza okazała się forma i wartość estetyczna pozyskanych materiałów audiowizualnych. Spacery były niekiedy oceniane pod kątem sposobów wypowiadania się przewodników i tego, czy narracja może zaciekawić potencjalnego odbiorcę. Spodziewano się poruszania coraz to nowych tematów zamiast pogłębiania tych już znanych. Jest to jak najbardziej zrozumiałe ze względu na charakter tej instytucji i cele, jakie przed sobą stawia, na przykład animację społeczności lokalnej czy popularyzowanie wiedzy o mieście. Warto było jednak na początku prac zaznaczyć, że oczekiwania badaczy mogą być inne, a powtarzanie się tematów nie jest wadą badań, ale ciekawą wskazówką analityczną, przy czym forma spaceru i sposób wypowiadania się przewodników jest wtórny wobec jego treści.

W trakcie realizacji projektu wybrane spacery były na bieżąco prezentowane w przestrzeni publicznej. Odbywało się w ramach comiesięcznych wydarzeń 
o charakterze kulturalnym, artystycznym i społecznym, będących również elementem Strefy, tzw. niedziel na Świętym Marcinie. Niezależnie od uwzględnienia wspomnianych wcześniej aspektów prawnych i etycznych, czyli podpisania umowy o upublicznieniu wizerunku i uprzedzenia przewodników przed realizacją spacerów o późniejszych publicznych projekcjach, byli oni informowani o miejscu i czasie gdy znano już dokładny termin prezentacji. Jednakże zdecydowana większość z nich nie pojawiła się podczas prezentacji, co można uznać za duży niedostatek projektu w kwestii jego oddziaływania społecznego. Można przypuszczać, że przyczyną było miejsce prezentacji spacerów, kojarzone bezpośrednio $z$ instytucjami kulturalnymi, co dla niektórych mogło stanowić pewną barierę mentalną związaną $z$ wejściem $z$ nieznaną przestrzeń. Lepszym rozwiązaniem byłoby zorganizowanie projekcji w miejscach bardziej związanych ze społecznością lokalną (np. na podwórkach przy ulicy). Lokalizacja określa bowiem w dużym stopniu grupę docelową, do której trafiają rezultaty projektu. Można oczywiście założyć inny społeczny cel, czyli propagowanie wiedzy i wspomnień o Świętym Marcinie wśród szerszej grupy poznaniaków. Wydaje się jednak, że uwzględnienie aspektów interwencyjnych, związanych z budowaniem więzi społecznych wśród dotychczasowych mieszkańców, przyniosłoby większą korzyść społeczną.

\section{PODSUMOWANIE \\ — PERSPEKTYWY ROZWOJU MIEJSKICH BADAŃ SPOŁECZNYCH W RUCHU}

Można oczekiwać, że rola miejskich BSR będzie coraz większa. Wynika to zarówno ze wzrostu roli mobilności jako elementu życia społecznego w mieście, jak i z nowych tendencji teoretyczno-metodologicznych w naukach społecznych. Wskazać można trzy aspekty wyznaczające perspektywy rozwoju miejskich BSR.

Pierwszy to zarysowująca się od jakiegoś czasu tendencja do odchodzenia od badań opartych na narracjach słowno-wizualnych. Kilkunastoletni rozwój metod wizualnych w badaniach społecznych to bez wątpienia okres poszukiwania nowych sposobów zbierania danych i aktywizowania refleksyjności badanych. Wydaje się jednak, że wraz z dalszym rozwojem kultury wizualnej i swoistym spowszednieniem kontaktu $z$ reprezentacjami wizualnymi metody wizualne częściowo tracą dotychczasowy potencjał. Niezbędne są nowe formy aktywizowania badanych, odnoszące się do różnych przestrzeni aktywności. BSR jako uzupełnienie metod wizualnych są bez wątpienia odpowiedzią na takie potrzeby.

Po drugie, upowszechnienie różnego rodzaju urządzeń technicznych sprawia, że stają się one oczywistym i naturalnym elementem życia codziennego. Co za tym idzie, wzrasta również ich potencjał mobilności - zarówno na poziomie proponowanych rozwiązań technologicznych, jak i ich społecznej percepcji. BSR w coraz większym stopniu będą więc mogły wykorzystywać mniej 
profesjonalne formy rejestrowania, na przykład prywatne smartfony przewodników. Także rozwój profesjonalnych technologii, na przykład wspomnianych wcześniej kamer GoPro, może w znaczący sposób wpłynąć na badania w ruchu.

Po trzecie, rozwój technologii będzie zmieniał także potencjał komunikacyjny rezultatów BSR. Zwiększonym możliwościom wytwarzania materiałów badawczych będą towarzyszyły większe możliwości ich rozpowszechniania. BSR mogą więc stać się okazją do rozwoju i popularyzacji badań interwencyjnych w naukach społecznych. Choć oczywiście pociąga to za sobą nowe wyzwania prawne i etyczne, związane $z$ ochroną osób zaangażowanych $w$ proces badawczy.

\section{BIBLIOGRAFIA}

Bachmann-Medick Doris, 2012, Cultural turns. Nowe kierunki w naukach o kulturze, tłum. Krystyna Krzemieniowa, Oficyna Naukowa, Warszawa.

Bauman Zygmunt, 2006, Płynna nowoczesność, tłum. Tomasz Kunz, Wydawnictwo Literackie, Kraków.

Bean Jonathan, 2008, Beyond Walking with Video: Co-Creating Representation, „Epic”, s. 104-115.

Benjamin Walter, 2010, Pasaże, tłum. Rolf Tiedermann, Wydawnictwo Literackie, Kraków.

Bødker Mads, 2014, Walking, Sensing, Participation: Three Meditations for Experiential Computing, Proceedings of the European Conference on Information Systems (ECIS), Tel Aviv, Israel, 9-11 czerwca.

Brighenti Andrea Mubi, 2010, Visibility in Social Theory and Social Research, Palgrave Macmillan, Basingstoke-New York.

Burgin Victor, 1996, In/different Spaces: Place and Memory in Visual Culture, University of California Press, Berkeley.

Cameron Carla, Smith Catherine M., Tumilty Steve, Treharne Gareth J., 2014, The Feasibility and Acceptability of Using Mobile Methods for Capturing and Analysing Data about Dog-Walking and Human Health, „New Zealand Journal of Physiotherapy”, t. 42, nr 2, s. 163-169.

Carpiano Rchard M., 2009, Come Take a Walk with Me: The 'Go-Along' Interview as a Novel Method for Studying the Implications of Place for Health and Well-Being, „Health and Place”, t. 15, s. 263-272.

Castells Manuel, 2013, Władza komunikacji, tłum. Jakub Jedliński, Paweł Tomanek, Wydawnictwo Naukowe PWN.

Certeau Michel, de, 2008, Wynaleźćc codzienność. Sztuki działania, tłum. Katarzyna Thiel-Jańczuk, Wydawnictwo Uniwersytetu Jagiellońskiego, Kraków.

Clark Andrew, Emmel Nick, 2010, Realities Toolkit \#13: Using Walking Interviews (eprints.ncrm.ac. uk/1323/1/13-toolkit-walking-interviews.pdf [15.05.2016]).

Doy Gen, 2005, Picturing the Self. Changing Views of the Subject in Visual Culture, I.B. Tauris, New York.

Emmel Nick, Clark Andrew, 2009, The Methods Used in Connected Lives: Investigating Networks, Neighbourhoods and Communities, NCRM Working Paper. National Centre for Research Methods (http://eprints.ncrm.ac.uk/800/1/2009_connected_lives_methods_emmel_clark.pdf).

Giddens Anthony, 2006, Nowoczesność i tożsamość. „Ja” $i$ społeczeństwo w epoce późnej nowoczesności, tłum. Alina Szulżycka, Wydawnictwo Naukowe PWN, Warszawa.

Guest Greg, Namey Emily E., Mitchell Marilyn L., 2013, Collecting Qualitative Data. A Field Manual for Applied Research, Sage, Thousand Oaks.

Heath Christian, Hindmarsh Jon, 2002, Analysing Interaction. Video, Ethnography and Situated Conduct, w: Tim May (red.), Qualitative Research in Action, Sage Publications, London. 
Henley Paul, 2005, Putting Film to Work: Observational Cinema as Practical Ethnography, w: Sarah Pink, László Kürti, Ana Isabel Afonso (red.), Working Images. Visual Research and Representation in Ethnography, Routledge, London-New York.

Howes David, 2010, Response to Sarah Pink, „Social Anthropology”, t. 18, nr 3, s. 333-336.

Ingild Tim, 2000, The Perception of Environment. Essays on Livelihood, Dwelling and Skill, Routledge, London-New York.

Jones Phil, Bunce Griff, Evans James, Gibbs Hannah, Hein Jane Ricketts, 2008, Exploring Space and Place With Walking Interviews, ,Journal of Research Practice”, t. 4, nr 2, s. 1-9.

Kusenbach Margarethe, 2003, Street Phenomenology: The Go-Along as Ethnographic Research Tool, „Ethnography”, t. 4, s. 455-485.

Lynch Kevin, 1990, The Image of the City, The MIT Press, Cambridge-London.

Meyer Kurt, 2008, Rythms, streets, cities, w: Kanishka Goonewardena, Stefan Kipfer, Richard Milgrom, Christian Schmid (red.), Space, Difference, Everyday Life: Reading Henri Lefebvre, Routledge, London-New York.

Mills Kathy, Comber Barbara, Kelly Pippa, 2013, Sensing Place: Embodiment, Sensoriality, Kinesis, and Children behind the Camera, „English Teaching: Practice and Critique September”, t. 12, nr 2, s. 11-27.

Moussaïd Mehdi, Perozo Niriaska, Garnier Simon, Helbing Dirk, Theraulaz Guy, 2010, The Walking Behaviour of Pedestrian Social Groups and Its Impact on Crowd Dynamics, „PLoS ONE”, 5(4): e10047 (doi:10.1371/journal.pone.0010047).

Parkin Stephen, Coomber Ross, 2009, Value in the Visual: On Public Injecting, Visual Methods and their Potential for Informing Policy (and Change), „Methodological Innovations Online”, t. 4(2), s. 21 $-36$.

Pasqualino Caterina, 2007, Filming Emotion. The Place of Video in Anthropology, „Visual Anthropology Review", t. 23, nr 1, s. 84-91.

Pink Sarah, 2006, The Future of Visual Anthropology: Engaging the senses, Routledge, London-New York.

Pink Sarah, 2007, Walking with Video, „Visual Studies”, t. 22, nr 3, s. 240-252.

Pink Sarah, 2010, The Future of Sensory Anthropology / The Anthropology of the Senses, „Social Anthropology", t. 18, s. 331-333.

Pink Sarah, Leder Mackley Kerstin, 2012, Video and a Sense of the Invisible: Approaching Domestic Energy Consumption through the Sensory Home, „Sociological Research Online”, 17(1) (doi: $10.5153 /$ sro.2583).

Postma Metje, 2006, From Description to Narrative: What's Left of Ethnography, w: Peter Ian Crawford, Metje Postma (red.), Reflecting Visual Ethnography. Using the Camera in Anthropological Research, P Leiden, Højberg.

Rewers Ewa, 2005, Post-polis. Wstęp do filozofii ponowoczesnego miasta, Universitas, Kraków.

Rogowski Łukasz, 2015, Estetyki lokalności. Miejska ikonosfera w perspektywie zwrotu przestrzennego, w: Jacek Kubera, Łukasz Rogowski (red.), Miasto w oczach ludzi. Wizualność wspótczesnej ikonosfery miejskiej, Wydawnictwo Naukowe Wydziału Nauk Społecznych UAM, Poznań.

Rost Mattias, Cramer Henriette, Holmquist Lars Erik, 2011, Mobile Exploration of Geotagged Photos, „Personal and Ubiquitous Computing”, t. 16, nr 6, s. 665-676.

Sheller Mimi, Urry John, 2006, The New Mobilities Paradigm, „Environment and Planning”, t. 38, s. 207-226.

Simmel Georg, 2006, Most i drzwi. Wybór esejów, tłum. Małgorzata Łukasiewicz, Oficyna Naukowa, Warszawa.

Stalder Felix, 2012, Manuel Castells. Teoria społeczeństwa sieci, tłum. Marek Król, Wydawnictwo Uniwersytetu Jagiellońskiego, Kraków.

Tatarkiewicz Władysław, 1999, Historia filozofii, t. 2, Wydawnictwo Naukowe PWN, Warszawa. 
WALKING WITH VIDEO:

STUDYING THE CITY FROM THE PERSPECTIVE OF THE MOBILITY PARADIGM

\section{Summary}

This article contains a presentation of the theoretical and methodological premises of various kinds of mobile social research in the city. The departure point is to treat moving as a characteristic of contemporary socio-cultural life, as in the premises of the mobility paradigm. Mobility is described as the context for experiencing the urban space and the point of departure for mobile social research. The traits and various types of such research are indicated, including the principles that connect them with visual research techniques. 'Walking with video' is used as an example. The author recounts research experiences connected with the use of this technique, on three levels: preparation, realization, and processing and communication.

\section{Key words / słowa kluczowe}

mobility / mobilność; city / miasto; mobile social research / badania społeczne w ruchu (BSR); visual research / badania wizualne; walking with video /wideozwiedzanie 